\title{
Implementation of Art and Technology in Batik Purwakarta
}

\author{
Ratnadewi $^{1}$, Ariesa Pandanwangi ${ }^{2}$, Agus Prijono ${ }^{3}$ \\ 1,3Department Electrical Engineering, Universitas Kristen Maranatha, Indonesia \\ ${ }^{2}$ Department Art and Design, Universitas Kristen Maranatha, Indonesia \\ 1ㅁatnadewi@eng.maranatha.edu, 2ariesa.pandanwangi@maranatha.edu, \\ 3agus.prijono@eng.maranatha.edu
}

\begin{abstract}
\section{Article History:}

Received : 26-02-2020

Revised : 27-03-2020

Accepted : 28-03-2020

Online : 02-04-2020

\section{Keyword:}

Batik Purwakarta; Graphics Turtle; Graphics Mathematic; Pseudocode.

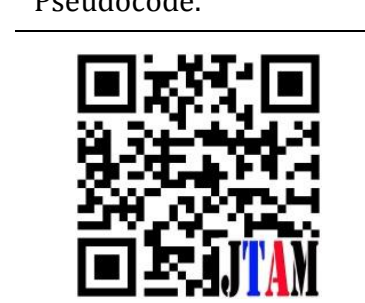

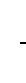

Indonesia is dominated by cities that have a history of batik, but Purwakarta does not have a history of batik. But thanks to the persistence of policyholders, Purwakarta currently has batik obtained by elevating the local wisdom of the city of Purwakarta. After surveys and interviews, several batik motifs were designed. The batik motif shape, size and position will be studied which will formulate mathematical equations based on basic geometric shapes such as circles, arches, lines, rectangles, which are implemented into the form of computer graphics (turtles) graph and explained in the form of an algorithm (pseudocode) computer programming to make auto generative motifs on Purwakarta batik that did not exist before. The batik design is inspired by food and tourist locations which form the basis of the formation of typical Purwakarta batik motifs. Jatiluhur Dam, Datura metel L. Flower, Sate Maranggi, Mangosteen Fruit is local wisdom owned by the city of Purwakarta. The results of the morning glory batik design and Jatiluhur dew through mathematical and turtle charts are then formulated so that the batik motif design can be saved by documenting the mathematical equation or the pseudocode of the batik motif. With the results of digital motifs, the process of repeating patterns, duplicating and storing data becomes easier.
\end{abstract}

\section{d.) 8 Crossref}

https://doi.org/10.31764/jtam.v4i1.1872 (c) (1) (0)

This is an open access article under the CC-BY-SA license

\section{A. INTRODUCTION}

One branch of mathematics is geometry which studies the size, graphs, comparisons, shapes, and positions (Novita, Putra, Rosayanti, \& Fitriati, 2018). From childhood to adulthood, from kindergarten children to college students, geometry is learned as a form of real learning. Geometry learning can be done in various ways, for example with pictures, visual aids, and digital activities (Bilai, Konca, \& Arıkan, 2019).

Research on the shape of a circle as a basic pattern of geometry, which is used to make batik motifs has been done by (Prastyo \& Mulyana, 2014). The basic pattern of a circle from an image is described, which is then mathematically formed through fractal geometry. Various new circle patterns can be produced by applying the basic pattern of the circle to the fractal formula because the concept of fractals can produce similarity of patterns at all scales. Furthermore, to make a variety of fractal patterns can be done in terms of graphics, colour, 
size and style, so that in the end it can overcome the problem of limited circle motifs. The motives produced are increasingly diverse from simple forms to unique shapes by utilizing computer devices and software applications and computer technology. The increasingly diverse and beautiful batik patterns can be produced with the existence of fractal-based circle patterns.

Qingni, Jian, \& Haisong (2016) in his research formed a butterfly motif on batik with mathematical equations on polar coordinates using the Matlab program. The results of the butterfly motif are then repeated with iterations based on the functions already obtained so that several variations are produced with one butterfly pattern.

Another research Wulandari, Purnomo, \& Kamsyakawuni (2017), the Labako batik pattern is described which is a typical batik pattern from the city of Jember. The origin of the term Labako from Madura: "La Bako", which describes the activities of farmers doing the planting and processing of tobacco leaves. In Labako batik, the form of tobacco leaves becomes the most important feature because Jember Regency is one of the best tobacco producing cities in Indonesia. The use of the L-System for the development of the Labako batik motif and then combining it with the fractal geometry of the dragon curve and utilizing modeling using Matlab software.

Documenting a digital image can be done by storing the intensity of all the pixels, if a digital image is 200 pixels x 300 pixels x 8-bit greyscale (200 is the number of pixels wide and 300 is the number of pixels high) then the memory required is at least $200 \times 300 \times 8$ bit $=$ 480000 bits. In this study, the motive is implemented with computer graphics to form graphs using mathematical equations or graphs and explained in the form of computer programming algorithms (pseudocode). By storing mathematical formulas in the form of a program, less memory is needed than storage in the form of images. With the use of mathematical formulas, the motifs can be modified more easily, motives can be auto generative more flexible and more efficient storage media, especially digitally.

The purpose of this study is to implement mathematical geometry by raising the potentials in Purwakarta by emphasizing the potential of the region such as the superior yield potential of Purwakarta agriculture, namely mangosteen fruit that has export quality, culinary potential, namely the famous satay maranggi food. Efforts that have resonated to the international level now through local government policy were conceived as batik motifs. The problem in this study is how to initiate the potential of the area into a superior batik motif which is also equivalent to the potential of other regions. The creative effort is poured into digital motifs through batik made with mathematical formulas.

Indonesia is dominated by cities that have a history of batik, but there are some cities, especially in West Java that do not have a history of batik. One example is Purwakarta, which previously did not have a history of batik but now it has succeeded in making it happen.

Currently, Purwakarta is experiencing a very significant investment growth. Strategic and dynamic position in West Java which is traversed by the arteries of trade, transportation and the national economy. One opportunity that continues to be encouraged is the birth of batik motifs that can raise local wisdom. Purwakarta is a district whose community grows and develops from thick history and tradition. Purwakarta has a variety of potentials capable of supporting regional expansion and development. Among others, the potential in the fields of 
economy, industry, agriculture and tourism. With its cultural capital and potential, Purwakarta has become a dynamic and growing area, without leaving its Sundanese tradition basic. Purwakarta is also known as the paradise of sate maranggi.

Now it is also developing the potential of its distinctive batik. The motifs of food and regional art are considered to be the main attraction. This can be realized into batik motifs and some of them have already been realized in the form of batik cloth, thanks to the persistence of policyholders. The potential of Purwakarta in elevating local wisdom into batik motifs is a long journey. The time series proves that it is not easy to realize a motif that is appointed into a batik motif. The problem raised in this paper is how is the local potential raised into batik motifs? Is the motive behind the story explicitly told to the public? How is the role of digitalization in developing batik motifs?. To answer these problems, we need a method in making the batik motif. This research begins by observing the design of batik motifs, then determining the geometrical forms that can be used similar to batik motifs, after which the equation is used to produce batik motifs either by making graphs with mathematical equations or with turtle charts.

For data storage needs that are simpler and require a little memory from the batik motif using "turtle graphics" or making graphs with mathematical equations "Turtle graphics" which produce batik motifs, will then be used as a reference for the initial batik patterns for the next process, namely the production of batik by hand or with a stamp, which will increase the productivity of batik making.

The above studies discuss batik patterns using various methods in the field of science. the difference with the research conducted by the research team is that batik motifs are derived from the potential and local wisdom in the Jatiluhur-Purwakarta area. As for the motifs made using mathematical graphs and turtle graphs, they will then be implemented onto a piece of batik cloth.

\section{B. METHODS}

The method used in making the motif begins with the method of surveying and interviewing, field exploration. The data obtained is reduced and the results are sorted and then sketched and the mathematical formula is made. This was later developed into the Jatiluhur batik motif.

One example is the famous food of Purwakarta which is famous for its satay maranggi as can be seen in Figure 1 (a) which was appointed as a batik motif as in Figure 1 (b) and Figure 1 (c). seen in Figure 1 (a) which was appointed as batik motif as in Figure 1 (b) and Figure 1 (c). Maranggi Satay is one of the typical culinary types of Purwakarta Regency which is made from diced pieces about $1 \mathrm{~cm}$ in size. 4 pieces of meat are put together parallel to the way pricked on a sharp bamboo blade Satay Maranggi measuring about $20 \mathrm{~cm}$. which is then seasoned and then baked until done (Setiawan, 2017). 


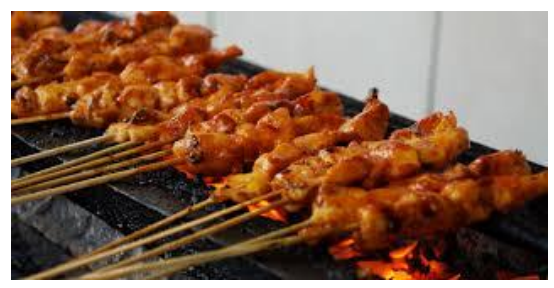

(a)

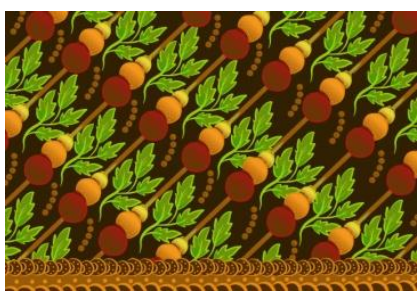

(b)

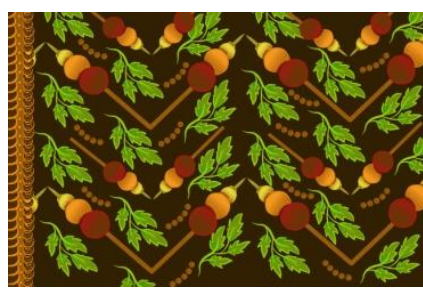

(c)

Figure 1. (a) Satay maranggi (b) Motif batik satay 1 (c) Motif batik satay 2 Source Figure 1(b,c). Ariesa Pandanwangi

Then the local mangosteen fruits such as Figure 2 (a) are raised into batik motifs as in Figure 2 (b) and Figure 2 (c).

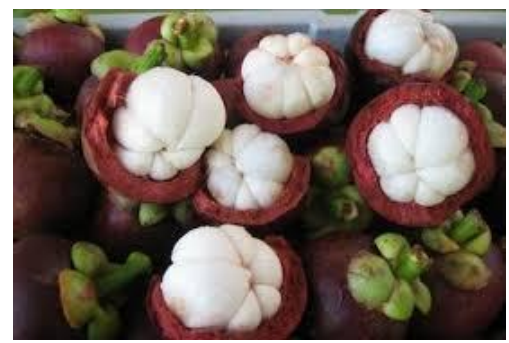

(a)

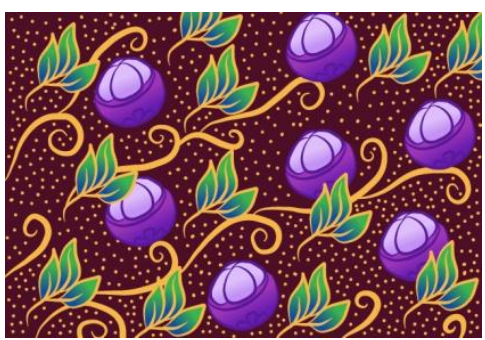

(b)

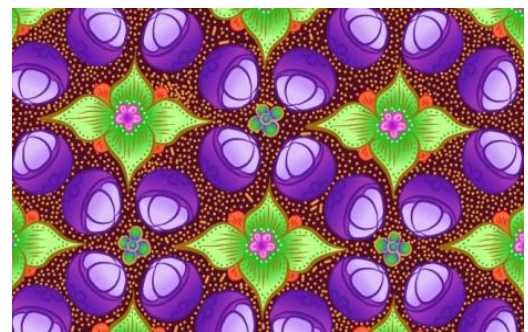

(c)

Figure 2. (a) Mangosteen fruit (b) Mangosteen batik motif 1 (c) Mangosteen batik motif 2 Source Figure 2(b,c). Ariesa Pandanwangi

There is also the natural wealth of Purwakarta namely the Datura metel L. flower as shown in Figure 3 (a), and the Jatiluhur dam in Figure 3 (b), inspiring the manufacture of morning glory batiks such as Figure 3 (c) and Figure 3 (d). One of the other inspirations comes from the water droplets produced by dew on the trees as shown in Figure 4 (a), which results in Jatiluhur dew motif designs as in Figure 4 (b) and Figure 4 (c).

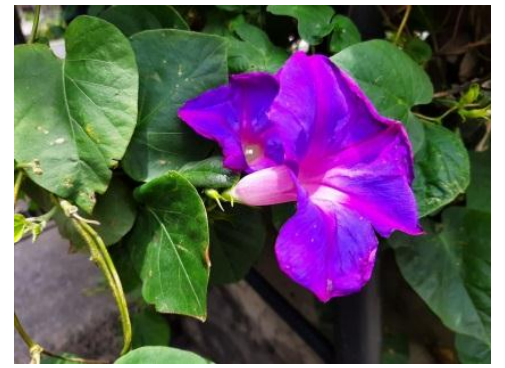

(a)

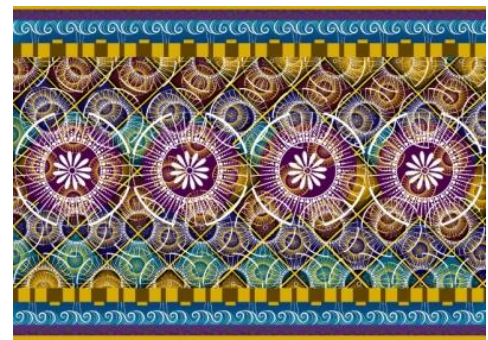

(c)

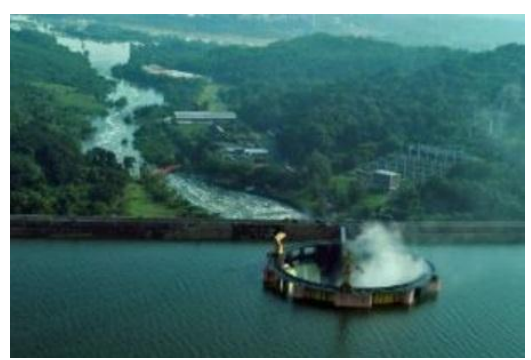

(b)

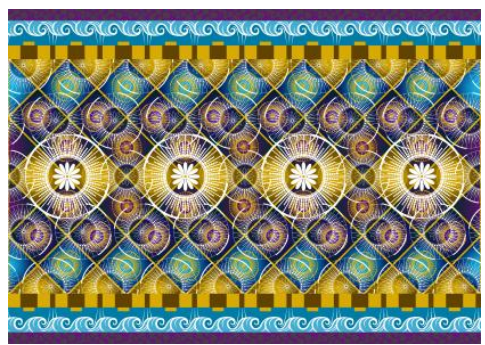

(d)

Figure 3. (a) Datura Metel L. flower (b) Jatiluhur Dam (Anonim, 2020)(c) Morning glory batik motif 1 (d) Morning glory batik motif 2 Source Figure 3(c,d). Ariesa Pandanwangi 


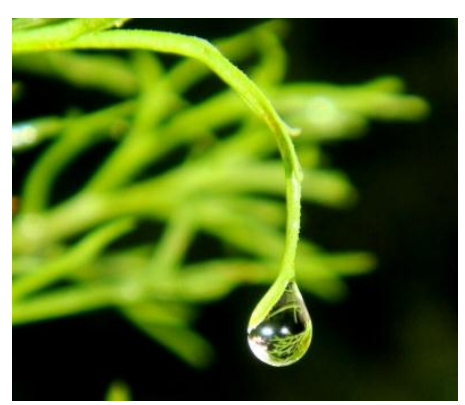

(a)

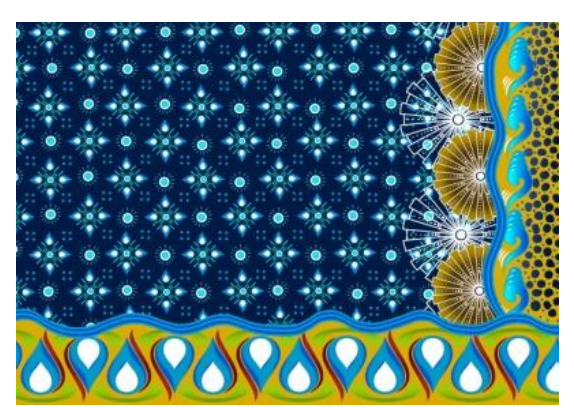

(b)

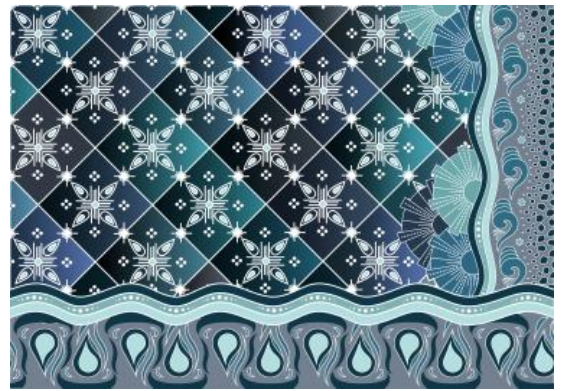

(c)

Figure 4. (a) Dew drops (Pixabay, n.d.) (b) Motifs of jatiluhur dew batik (c) Motives of jatiluhur dew batik

Source Figure 4(b,c). Ariesa Pandanwangi

The method for digitalization used in the implementation here is a turtle graphics and mathematics graphics (Lindenmayer, 2004). Turtle charts are used for arbitrary batik motifs and mathematical graphs are used for batik motifs that can be formulated using mathematical equations (Dobashi, Kaji, \& Iwasaki, 2019). Before drawing a graph turtle, the batik motif is sketched first on paper, then we formulate the graph equation. The basic idea of turtle interpretation is given below in Table 1 . The state of the turtle is defined as a triplet $(x, y, \alpha)$, with Cartesian coordinates $(\mathrm{x}, \mathrm{y}$ ) representing the position of the turtle, and the angle $\alpha$, called the heading (head), is interpreted as the direction the turtle faces. Given the step size $\mathrm{d}$ and the incremental angle $\delta$, the turtle can respond to the commands represented by the following symbols (Figure $5(\mathrm{a})$ ).

For example, see Figure 5(b), the turtle first faces upward then moves three steps forward, the turtle rotates 90 degrees to the right and moves 3 steps forward, rotates 90 degrees right, two steps forward and spin right 90 degrees forward two steps, spin left 90 degrees, go forward one step, spin right 90 degrees forward one step. This command can be abbreviated as FFF-FFF-FF-FF + F-F.

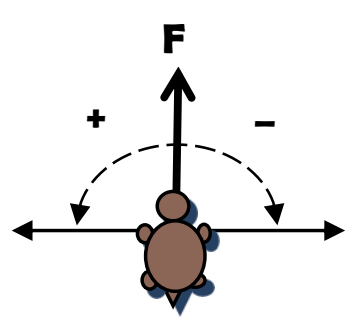

(a)

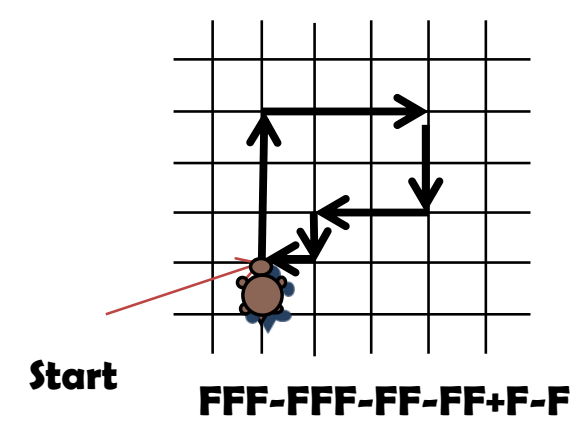

(b)

Figure 5. (a) Turtle interpretation of the string symbol F, +, -. (b) Interpretation of a string. Increased angle $\delta$ equals $90^{\circ}$. Initially the turtle faces upwards.

Table 1. Turtle graphics commands

\begin{tabular}{cll}
\hline Symbol & \multicolumn{1}{c}{ Interpretation } & \multicolumn{1}{c}{ Meaning } \\
\hline $\mathrm{F}$ & $\begin{array}{l}\text { Move forward and draw a } \\
\text { line }\end{array}$ & $\begin{array}{l}\text { Proceeding one step along d. The state of the turtle } \\
\text { changed to }\left(\mathrm{x}^{\prime}, \mathrm{y}^{\prime}, \alpha\right) \text {, with } \mathrm{x}^{\prime}=\mathrm{x}+\mathrm{d} \cdot \cos \alpha \text { and } \mathrm{y}^{\prime}=\mathrm{y}+\end{array}$ \\
\hline
\end{tabular}




\begin{tabular}{|c|c|c|}
\hline Symbol & Interpretation & Meaning \\
\hline & & $\begin{array}{l}\text { d.sin } \alpha \text {. Draw line segments between points }(\mathrm{x}, \mathrm{y}) \text { and } \\
\left(\mathrm{x}^{\prime}, \mathrm{y}^{\prime}\right) \text {. }\end{array}$ \\
\hline $\mathrm{f}$ & $\begin{array}{l}\text { Move forward } \\
\text { drawing a line }\end{array}$ & Go one step long $d$ without drawing a line \\
\hline+ & Turn left with the angle $\delta$. & $\begin{array}{l}\text { The state of the } \\
\text { orientation fro }\end{array}$ \\
\hline $\begin{array}{c}- \\
\text { push } \\
\end{array}$ & $\begin{array}{l}\text { Turn right with the angle } \delta \text {. } \\
\text { Remember the current state }\end{array}$ & $\begin{array}{l}\text { The next turtle state is }(\mathrm{x}, \mathrm{y}, \alpha-\delta) \\
\text { Remember the current state (position, angle, line col }\end{array}$ \\
\hline pop & $\begin{array}{l}\text { Restore the last remembered } \\
\text { state }\end{array}$ & $\begin{array}{l}\text { Restore the last remembered state and remove it from } \\
\text { the list of remembered states. }\end{array}$ \\
\hline
\end{tabular}

The mathematical formula for forming a graph of interest in the Cartesian coordinates for the $\mathrm{x}$ and $\mathrm{y}$ axes can be written as follows (Tian, Yuan, Hu, \& Shi, 2019)::

$$
\begin{aligned}
& x=a \cos (n t) \cos (t) \\
& y=a \cos (n t) \sin (t)
\end{aligned}
$$

Where $a$ is the radius of the flower, $t$ has a range from 0 to $2 \pi, \mathrm{n}$ is the number of flower petals.

To form a circle on the Cartesian coordinates for the $\mathrm{x}$ and $\mathrm{y}$ axes the equation is used:

$$
\begin{aligned}
& x=b \cos (t) \\
& y=b \sin (t)
\end{aligned}
$$

where $b$ is the radius of interest and $t$ has a range from 0 to $2 \pi$.

\section{RESULT AND DISCUSSION}

This research begins by observing the design of batik motifs, then determining the geometrical forms that can be used that are similar to batik motifs, after which the equation used to produce batik motifs is determined. In this study equation (1) is used to form a flower graph with $\mathrm{n}$ as the number of flower petals that will be formed by a mathematical graph. Equation (2) is also used to form a circle graph with radius $b$ to determine the size of the circle. Measurements are made to produce a mathematical graph that matches the size of the desired batik pattern.

\section{Morning Glory Batik}

The mathematical implementation of the morning glory batik pattern begins with making a mathematical graph of equation (1) to form a flower in the middle of the morning glory pattern, the number of petals in the pattern of 12 pieces, so that the variable $n=6$ in equation (1), which is half the number of flower petals want to be produced and $a=2.2$, which is the length of the desired flower petal. To form an edge circle, the equation of the circle equation

(2) is used with the value $b=3$ for the inner circle, and $b=6$ for the outer circle.

Morning Glory Batik is inspired by the many Datura metel L. flowers found in Purwakarta (Figure 6). There are two colours of Datura Metel L. flowers that grow wild on cliffs or the edge of the forest. White Datura Metel L. and purple Datura metel L.. This flower called Datura metel L. maybe purple like a gemstone or Datura metel L. agate. Maybe, on the contrary, purple agate is called Datura Metel L. because the colour is like Datura metel L.

The Datura metel L. flower is not very attractive, like a trumpet but looks upward. Odourless and smaller in shape than leaves so it is less attractive to be an ornamental plant though. Only the colours purple and white look beautiful. 


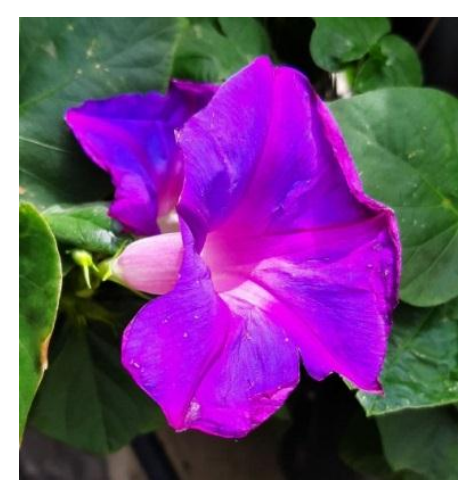

Figure 6. The Datura Metel L. Flower

Source: Research team. 2020

In the village where the weather is cold, these plants are easily found that grow wild or planted in the yard for herbal medicine or family medicinal plants. This plant is believed to relieve pain, for example teeth or pain by smearing it. But some people use Datura Metel L. as a plant to anesthetize (Gente, Leman, \& Anindita, 2015). When circumcision rituals are performed traditionally using sharp pieces of bamboo skin in Javanese called pring silatan without anesthetic. Of course, the pain is very deep to the crown and like piercing the solar plexus.

This extreme pain makes restless and difficult to sleep. At night when the pain does not go away. Efficacy of Datura Metel L. that can make someone anesthetized, by some people misused to a little forget the world with drunken fun. If intoxication with intoxication usually lasts between 1 or 2 hours, the Datura Metel L. intoxication can last for two or three days. Getting drunk from the Datura Metel L. hallucinates the brain with strange shadows. For example, the poster image in front can be the face of people who curse us and make us afraid.

Datura Metel L. flower extract can also be used as an insecticide, to kill mosquitoes that interfere and cause disease (Martini, Astriana, Yuliawati, Hestiningsih, \& Purwantisari, 2018). In addition to the Datura Metel L. which inspired the morning glory batik motif, the Jatiluhur dam was built in a circle (Figure 3 (b)). Jatiluhur Dam is also one of the ideas in making batik motifs.

Ir Djuanda Dam (Jatiluhur), Purwakarta district, is a multifunctional artificial dam in West Java (Purwakarta, 2018). Including, becoming a favourite tourist attraction. Its beauty is no doubt. No wonder, if until now the area still has an extraordinary charm for tourists. Inundation that occurred due to the construction of the Jatiluhur Dam submerged 14 villages with a population of 5,002 people. The residents were then partly moved to the area around the dam and the other part moved to Karawang Regency. Most of the population at that time worked as farmers.

The dam was built starting in 1957 with the laying of the first stone by the first Indonesian President Ir Soekarno and was inaugurated by President Soeharto on August 26, 1967. The construction of the Jatiluhur Dam dam cost USD 230 million. The name of the dam is called Ir. H. Djuanda due to commemorate his services in fighting for the financing of the construction of the Jatiluhur Dam. He is the last Prime Minister of the Republic of Indonesia and led the cabinet of Karya (1957-1959) together with Ir. Sedijatmo is determined to fight for the realization of the Jatiluhur project in the Indonesian Government and international forums. 
As the manager of the artificial dam, Perat Jasa Tirta (PJT) II Jatiluhur, transformed the Jatiluhur Dam, from what was originally only for water reserves, has now become one of the leading tourist attractions (Okezone, 2020). The idea begins by illustrating the Datura Metel L. flower in the middle of the Jatiluhur dam, so the morning glory motif is obtained, the flower in the middle and surrounded by a circle symbolizing the Jatiluhur dam and the water flow in the Jatiluhur dam is symbolized by small circles around the circle.

Table 2 is pseudocode of graphics mathematics morning glory batik with circle outer, used equation (1) and (2). Figure 7 (a) is a batik morning glory motif inspired by Datura metel L. and jatiluhur dams, and Figure 7 (b) is a batik morning glory result. If stored in the form of memory images that are used $20 \mathrm{~KB}$ whereas if the Matlab program is stored in $1 \mathrm{~KB}$, it saves 20 times.

Table 2. Preudocode flower motif

\begin{tabular}{|c|c|}
\hline \multicolumn{2}{|c|}{ Pseudocode flower motif } \\
\hline 1 & procedure A \\
\hline 2 & $a \leftarrow 2.2$ \\
\hline 3 & $\mathrm{n} \leftarrow 6$ \\
\hline 4 & for $i \leftarrow 1$ to 360 do \\
\hline 5 & $t(i) \leftarrow i * p i / 180$ \\
\hline 6 & $x(i)=a{ }^{*} \cos (n \cdot t(i)) * \cos (t(i)) ;$ \\
\hline 7 & $y(i)=a{ }^{*} \cos (n \cdot t(i)) * \sin (t(i)) ;$ \\
\hline 8 & $\mathrm{xl}(\mathrm{i})=0.3 \mathrm{cos}(\mathrm{t}(\mathrm{i}))$; make circle in flower $r=0.3$ \\
\hline 9 & $y 1(i)=0.3 \sin (t(i)) ;$ \\
\hline 10 & $x 2(i)=3 \cos (t(i)) ;$ omake circle outside flower $r=3$ \\
\hline 11 & $y^{2}(i)=3 \sin (t(i)) ;$ \\
\hline 12 & $\mathrm{x} 3(\mathrm{i})=6 \cos (\mathrm{t}(\mathrm{i})) ;$ make circle outer flower $r=5$ \\
\hline 13 & $y^{3}(i)=6 \sin (t(i)) ;$ \\
\hline 14 & end for angle $\leftarrow \operatorname{dir} * 7.756$ \\
\hline 15 & $\operatorname{plot}(x, y, x 1, y 1, x 2, y 2, x 3, y 3)$ \\
\hline 16 & for $i \leftarrow 1$ to 360 do \\
\hline 17 & if $\bmod (i, 12)==0$ \\
\hline 18 & make line from circle $r=3$ to $r=6$ \\
\hline 17 & end \\
\hline 18 & end for \\
\hline
\end{tabular}

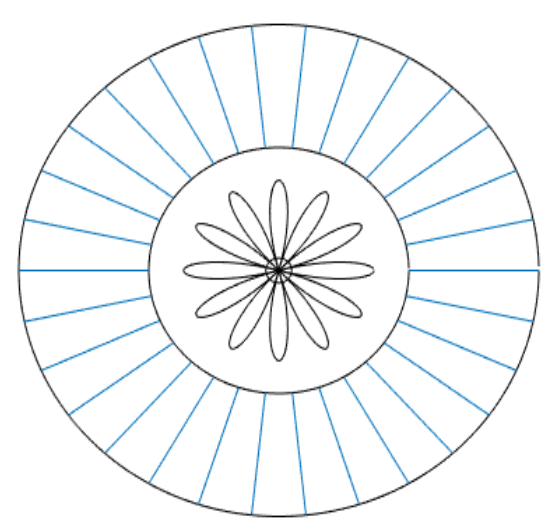
Figure 7. (a) Morning Glory from graphics mathematics (b) Batik
Source Figure 7(b). Ariesa Pandanwangi

(b)

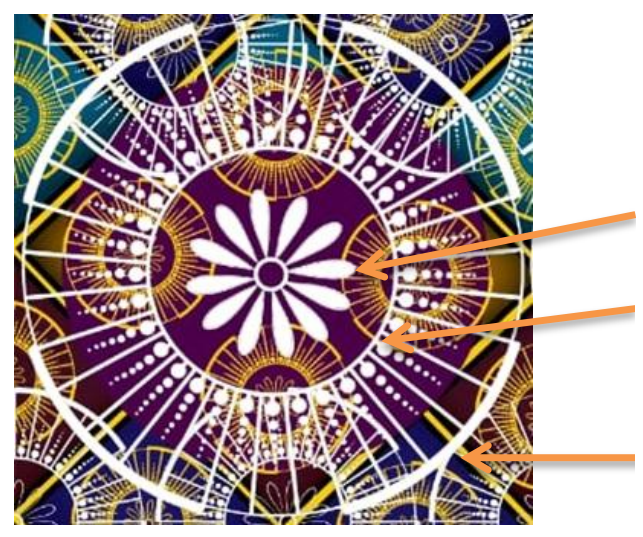

flower

circle outside flower

circle outer flower 


\section{Batik embun jatiluhur}

In the dew pattern of Jatiluhur batik here a turtle chart is used. The pattern is traced along the edge by determining the steps that must be taken by the tortoise so that the edge of the pattern can be traced correctly. The steps to trace the edge of the Jatiluhur dew batik pattern begins by tracing the edge of the water droplets, the middle circle, the decoration lines in the middle of the pattern, 3 small circle trimming edges, the edge decoration lines. In the pseudocode (Table 3), the tortoise graph algorithm will be made clear.

The basic idea of the Jatiluhur dew batik pattern can be explained as follows: Dew is a water vapour which undergoes a process in the condensation-the process of changing gas into a liquid. Dew usually appears in the morning, between the window glass or behind a leaf. According to the Indonesian dictionary, dew is defined as dots of water that fall from the air at night. In general, dew is water dots attached to the leaves and grasses that are often found in the morning or before the sun's heat on the leaves (Pendidikan, 2020).

In this case all day things absorb heat from the sun, on the contrary, at night things lose heat. When objects near the ground cool down, the temperature of the surrounding air also decreases. Cooler air can't hold as much moisture as warmer air. The process of dew is caused by differences in air temperature. If the temperature gets colder, the air will eventually reach the dew point. Dew point is the temperature when the air is still able to hold as much moisture as possible. If the temperature gets colder, some water vapour will condense on the surface of nearby objects, for example on the leaves of plants. Dew forms well on a clear, calm night. Dew also forms well when humidity is high, on the contrary when the sky is cloudy objects cool longer because clouds re-radiate heat to the earth. Which when the wind blows, the air needs more time to get cold near the dew point. In areas where temperatures can reach minus below zero degrees Celsius, dew can be found in the form of ice crystals. This dew is called frost or white dew. If a lot of dew will gather and drip into dew drops.

This dewdrop is the idea of forming the Jatiluhur dew batik motif. because in the Jatiluhur reservoir in the morning when the air reaches the dew point there are many dewdrops on the leaves of the trees. Table 3 is the pseudocode of graphics turtle dew drops (embun) Jatilluhur batik.

Table 3. Turtle graphics embun jatiluhur

\begin{tabular}{lc}
\hline \multicolumn{4}{l}{ Pseudocode Turtle graphics embun jatiluhur } \\
\hline 1 & procedure $A$ \\
\hline 2 & make dew drops \\
\hline 3 & copy dew drops 3 times \\
\hline 4 & rotate each dew drops pi/2 \\
\hline 5 & translate dew drops \\
\hline 6 & make little dew drops \\
\hline 7 & copy little dew drops 3 times \\
\hline 8 & rotate each little dew drops pi/2 \\
\hline 9 & make circle centre \\
\hline 10 & make ornamental line 1 \\
\hline 11 & copy ornamental line 1, 3 times \\
\hline 12 & matate each ornamental line l, pi/2 \\
\hline 13 & make ornamental line 2 \\
\hline 14 & copy ornamental line 2, 3 times \\
\hline 15 & rotate each ornamental line 2, pi/2 \\
\hline 16 & end procedure
\end{tabular}


Figure 7 (a) is the motif of jatiluhur dew batik results from the turtle graphic, Figure 7 (b) is the motif of jatiluhur dew batik after becoming batik cloth. In Figure 8 (a) the Jatiluhur dew batik motif is rotated 45 degrees so that it can be used for different batik designs. Figure 8 (b) is the result of jatiluhur dew batik motif on batik cloth. Once combined with the morning glory batik motif, the dew jatiluhur batik motif will look like Figure 4 (b) and Figure 4 (c). If stored in the form of memory images that are used 20KB whereas if the Mupadnya program is stored $13 \mathrm{~KB}$, there is a reduction in memory to save.

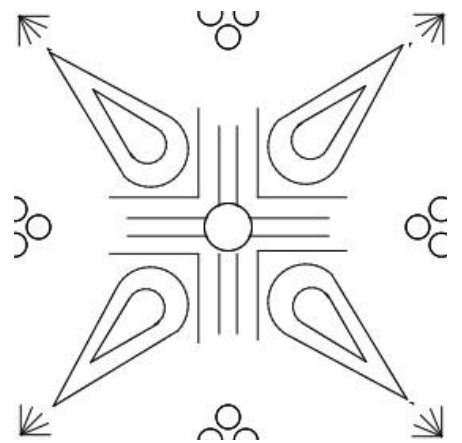

(a)

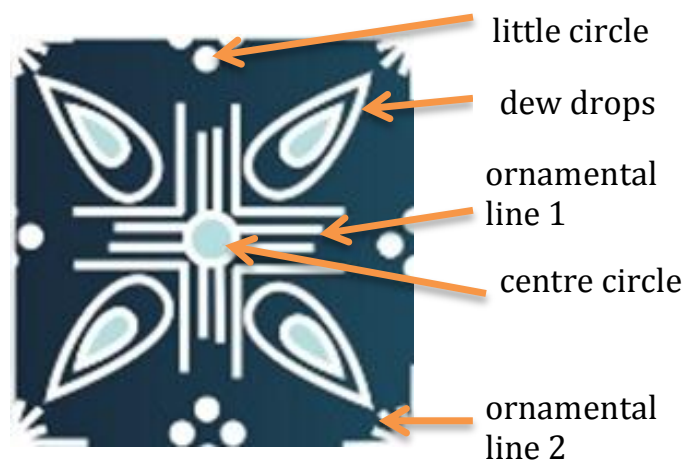

(b)

Figure 8. (a) embun jatiluhur from graphics mathematics (b) Batik design embun jatiluhur Source Figure 7(b). Ariesa Pandanwangi

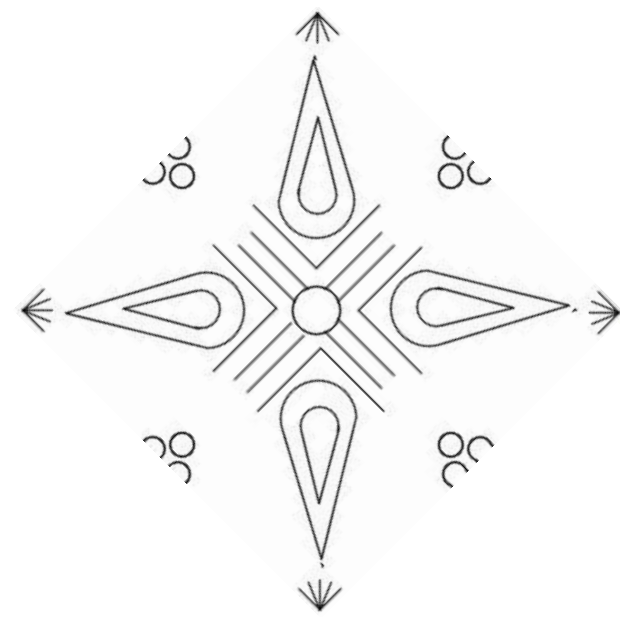

(a)

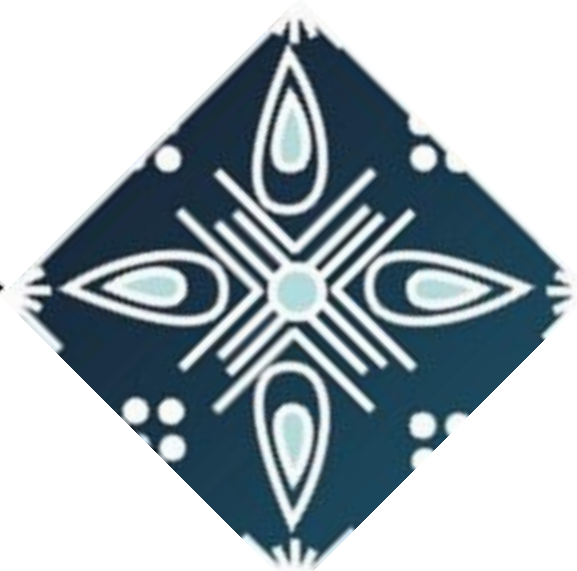

(b)

Figure 9. (a) embun jatiluhur from graphics mathematics (b) Batik design embun jatiluhur Source Figure 8 (b). Ariesa Pandanwangi

\section{CONCLUSION AND SUGGESTIONS}

Batik Purwakarta which is a new batik survey results and interviews can be made in digital form with the help of mathematical graphs and turtle charts, so it is expected that the process of making Purwakarta batik products can be more efficient when making basic motifs. With the results of digital motifs, the process of duplicating and storing data becomes easier. In the next research, it is hoped that other batik motifs can be digitized with the help of mathematical graphs and turtle charts. 


\section{ACKNOWLEDGEMENT}

Thank you so much for funding support that makes this research possible, to Direktorat Riset dan Pengabdian Masyarakat, Direktorat Jenderal Penguatan Riset dan Pengembangan Kementerian Riset, Teknologi, dan Pendidikan Tinggi Republik Indonesia in accordance with research contract of the year 2020 and thank you for facilities and support to Universitas Kristen Maranatha.

\section{REFERENCES}

Adnyana, I. P. W., Kesiman, M. W. A., \& Wahyuni, D. S. (2013). Pengembangan Aplikasi Pembuatan Pola Motif Batik Dengan Menggunakan Pengolahan Citra Digital. Jurnal Nasional Pendidikan Teknik Informatika (JANAPATI), 1(2), 164-172.

Anonim. (2020). Waduk Jatiluhur. Retrieved from https://1.bp.blogspot.com/ELvnszSOVa4/VuEAtFHzjgl/AAAAAAAAHNY/w2Cv7z94ZSw/s1600/waduk\%2Bjatiluhur\%2B1... jpg

Bilai, Ö., Konca, A. S., \& Arıkan, N. (2019). Children';s Geometric Understanding through Digital Activities: The Case of Basic Geometric Shapes. International Journal of Progressive Education, 15(3), 108-122. https://doi.org/10.29329/ijpe.2019.193.8

Dewi, R A M, D. (2016). Geometri Fraktal untuk Re-Desain Motif Batik Gajah Oling Banyuwangi. Jurnal Pendidikan Matematika, 5(2), 222-230.

Dobashi, Y., Kaji, S., \& Iwasaki, K. (2019). Mathematical Insights into Advanced Computer Graphics Techniques (Vol. 32). Japan: Springer. https://doi.org/10.1007/978-981-13-2850-3

Garnadi, A. D., Guritman, S., Kusnanto, A., \& Hanum, F. (2012). Survey Pola Grup Kristalogi Bidang Ragam Batik Tradisional. Journal of Mathematics and Its Applications, 11(2), 1. https://doi.org/10.29244/jmap.11.2.1-10

Gente, M., Leman, M. A., \& Anindita, P. S. (2015). Uji Efek Analgesia Ekstrak Daun Kecubung (Datura metel L.) Pada Tikus Wistar (Rattus norvegicus) Jantan. Jurnal E-GIGI, 3(2). https://doi.org/10.35790/eg.3.2.2015.9838

Hariadi, Y., Lukman, M., \& Destiarmand, A. H. (2013). Batik Fractal : actal : Marriage of Art and Science. ITB Journal Vis. Art \& Des, 4(1), 84-93. https://doi.org/10.5614/itbj.vad.2013.4.1.9

Lindenmayer, A. (2004). The algorithmic beauty of plants. New York: Springer-Verlag.

Marom, S. (2017). Application of Fractal Concept in Material Batik Development Based on Wolframs Mathematica. ZERO: Jurnal Sains, Matematika Dan Terapan, 1(2), 49-61. https://doi.org/10.30829/zero.v1i2.1461

Novita, R., Putra, M., Rosayanti, E., \& Fitriati, F. (2018). Design learning in mathematics education: Engaging early childhood students in geometrical activities to enhance geometry and spatial reasoning. Journal of Physics: Conference Series, 1088. https://doi.org/10.1088/1742$6596 / 1088 / 1 / 012016$

Okezone. (2020). Sejarah waduk jalituhur. Retrieved from https://news.okezone.com/read/2019/10/15/525/2117030/sejarah-waduk-jatiluhur-14-desaberkorban-untuk-tenggelam-demi-cadangan-air-jabar

Pendidikan, D. (2020). Pengertian Embun Serta Proses Terjadinya Lengkap. Retrieved from dosenpendidikan.co.id

Pixabay. (n.d.). Tetes embun. Retrieved from pixabay.com

Prasetyo, H., \& Simatupang, J. W. (2019). Batik Image Retrieval Using Maximum Run Length LBP and Sine-Cosine Optimizer. ICSECC 2019 - International Conference on Sustainable Engineering and Creative Computing: New Idea, New Innovation, Proceedings, 265-269. https://doi.org/10.1109/ICSECC.2019.8907190

Prastyo, A., \& Mulyana, T. M. S. (2014). Aplikasi Pola Batik Menggunakan Metode Fraktal dan Algoritma Lingkaran 8 Way Simetris. Jurnal Teknologi Informasi, 10(2), 1-9.

Purwakarta, K. (2018). Sejarah Bendungan Jatiluhur. Retrieved from purwakartakab.go.id

Qingni, Y., Jian, L., \& Haisong, H. (2016). Auto-Generation Method of Butterfly Pattern of Batik Based on 
Fractal Geometry. International Journal of Signal Processing, Image Processing and Pattern Recognition, 9(4), 379-392.

Saefurrohman, \& Ningsih, D. H. U. (2016). Desain Motif Batik Dengan Metode Fraktal Dan Algoritma LSystem untuk Membangun Pustaka Batik Wali. Dinamik, 21(1), 42-51.

Setiani, E. D., \& Suyoto, S. (2010). New Edge Detection Method Using Elisabeth Method: Case Study Javanese Batiks. Jurnal Buana Informatika, 1(1), 47-56. https://doi.org/10.24002/jbi.v1i1.289

Setiawan, I. (2017). Sate Maranggi: Kuliner Khas Kabupaten Purwakarta. Patanjala : Jurnal Penelitian Sejarah Dan Budaya, 9(2), 277. https://doi.org/10.30959/patanjala.v9i2.9

Shidi, T. A. P., \& Suyoto. (2011). New Edge Detection Method for Indonesian Batik. Jurnal Buana Info, 2(1), 55-62.

Tian, G., Yuan, Q., Hu, T., \& Shi, Y. (2019). Auto-generation system based on fractal geometry for batik pattern design. Applied Sciences (Switzerland), 9(11). https://doi.org/10.3390/app9112383

Wulandari, E. Y., Purnomo, K. D., \& Kamsyakawuni, A. (2017). Pengembangan Desain Batik Labako Dengan Menggabungkan Geometri Fraktal Kurva Naga dan Corak Daun Tembakau ( Development of Labako Batik Design with Fractal Geometry Dragon Curve and Tobacco Leaf Motif Combonation ). Jurnal Ilmu Dasar, 18(2), 125-132. 